\title{
Antecedents of Environmental Buying Behavior: Case of the Jordanian Market
}

\author{
Firas Jamil Al-Otoum ${ }^{1}$ \& Rawan S. Nimri ${ }^{2}$ \\ ${ }^{1}$ Marketing department, Isra university, Amman, Jordan \\ Correspondence: Firas Jamil Al-Otoum, Marketing department, Isra university, Amman, Jordan. E-mail: \\ otoum5@yahoo.com
}

Received: July 6, 2015

Accepted: July 17, 2015

Online Published: August 22, 2015

doi:10.5539/ijbm.v10n9p240

URL: http://dx.doi.org/10.5539/ijbm.v10n9p240

\begin{abstract}
This study attempts to gain insight about the factors effecting environmental buying behavior. Moreover, this study tries to present the findings in the Jordanian Market. It tries to present a vital source of information about what works in appealing the Jordanian consumer since the environmental buying behavior among Jordanians is still at its preliminary stages. In addition, this study tries study differences between the consumer's characteristics namely: age, educational level and income level and the environmental buying behavior.

The study sample consisted of 400 respondents. A total of 342 questionnaires were returned. The response rate of the survey was $85 \%$. Multiple Regression and One Way ANOVA and Tukey's post hock tests were applied to verify the research framework. Results showed that both green awareness and green trust have direct impact on environmental buying behavior. In addition, statistical differences in environmental buying behavior were found due to the education and income levels.
\end{abstract}

Keywords: green consumer, environmental buying behavior, green awareness, green trust, demographic factors, Jordan

\section{Introduction}

Over the years, consumers' awareness regarding the environment is being more evident in their buying behavior. People are paying more attention to environmental issues which have led to an increased demand for green products. Nowadays, environmental issues have become a major concern for consumers who are trying to change their perceptions and consumption habits because of their direct effect on the earth's sustainability (Gul, 2013). Some of the major touch points concerning sustainability include air and water pollution, population growth, global warming, ozone exhaustion, augmented consumption, genetic engineering and loss of species variety (Sharma, 2011). Consumers nowadays are more alert about the consequences and results of their consumption habits. Researchers have argued that in order to encourage environmental buying behavior, green products should be available with sufficient information about the green values of these products and their contribution to the environmental sustainability (Mondejar et al., 2011). According to Axsen et al. (2012), green products are desired since they provide better quality in terms of health, in addition to their contribution to a sustainable future in comparison to non-green products, and this will also add an advantage for consumers who are willing to buy green products.

According to a study conducted by Abu-Elsamen and Al-Dmour (2011), few researchers have identified the green marketing practices in Jordan. In addition, green marketing has been studied from the businesses' side in the Jordanian market, and few studies were conducted on the consumers' side aiming to study the Jordanian consumer profile and his environmental buying behavior.

Previous literature suggested that green marketing should become a part of the businesses' strategies in order to gain a competitive advantage along with the growing environmental consciousness in this decade (Wu and Chen, 2014). But more thorough research should be conducted as households are increasingly comparing between the products' attributes and the products' greenness, taking into consideration that their greenness is being an essential factor affecting the buying decision (Kumar, 2012).

In 2012, the World Bank placed Jordan in the 'Upper Middle Income Group', indicating that green products can be affordable for some households in order to promote healthy habits and improved lifestyle, which gives green 
products an opportunity to compete in the Jordanian market.

\section{Literature Review}

\subsection{Green Marketing}

Many studies have indicated that consumers those days are willing to alter their consumption patterns in order to protect the environment (Axsen et al., 2012). Green marketing is now viewed as a holistic strategic management practice that fulfills the consumers' needs and does not have negative impact on the human and natural welfare (Sharma, 2011). Kadirov and Varey (2010) defined two major components of green marketing: 1) The usage of natural resources that are sustained or renewed. 2) Reduction of pollution and waste of the production and usage of the products. Furthermore, Akter (2012) has indicated that businesses should combine green interests when developing their marketing strategies. Firms should not only claim to be green or produce green packages, but it should also include the green concepts in developing, pricing, promoting, and distributing green products (Mohajan, 2011).

According to Chen (2010), businesses adopt green marketing for the following reasons:

- Getting the major advantages of green opportunities.

- Enhancing the firm's image.

- Raising the product's value.

- Enhancing the competitive advantage.

- Complying with environmental trends.

The developing countries have witnessed a great amount of environmental problems as water and air pollution have begun to pose the major effects of the environment corrosion on public health (Kumar, 2012).

According to World Health Organization (WHO) the key environmental areas of risk include: water and air quality, toxic materials and global environmental change. These environmental aspects directly affect the disease and disability rates especially in developing countries. For instance, air pollution, water and waste management are major issues affecting the environment in Saudi Arabia (Fanak, 2015). As for World Wide Fund for Nature (WWF), water pollution may be the largest challenge in Africa in addition to the population growth.

Therefore, the pressure of 'going green' is alarming governments and citizens in the Middle East region. Research indicates that third world countries are just becoming more aware of the environmental problems and that governments are stating new laws in order to protect the environment (Saleki et al., 2012). In the light of those findings green marketing should be used as a tool for protecting the environment for the future generation since it will have a major positive impact on environmental safety. The issue of the environmental protection should be brought down to the consumer level since so many environmental problems are associated with human consumption and practices (Zagata, 2012). Consumers proclaim that they depend on businesses to drive them to act in an ecological manner. A global survey showed that above 60 percent of consumers expect corporations to take the leading role in creating environmental awareness (Stanford Review). In addition, consumers should be responsible enough to protect the environment and take the lead in buying and consuming green products.

\subsection{Green Consumer}

One known definition for the green consumer is the individual who consciously seeks to minimize the negative impact of his actions on nature by trying to minimize resource and energy consumption, use of non-toxic substances and reduce of waste production (Hossan, 2013). This green consumer requires products to give minimum negative impact to the environment. Wu and Chen (2014) stated that the green consumer is influenced by two sets of determinants: external determinants (media, family, culture) and internal determinants (demographics, psychological variables).

The green consumer believes that the current environmental conditions represent serious problems facing the sustainability of the planet, whereas the traditional consumer who is less sensible to ecological issues believes that those environmental problems will be resolved by themselves (Carrete et al., 2012).

\subsection{Green Awareness}

Some of the factors that affected the emergence of green consumer awareness were: the increasing knowledge about environmental problems, media coverage, emergence of NGOs specialized in the green sector, and the existence of national and international legislations (Kulshrestha, 2013).

One of the major factors that affect the green purchase decision is the environmental awareness. As 
environmental issues are increasing worldwide, consumers' awareness regarding the green products and their usage has incremented as well (Ling, 2013). For instance, in Malaysia some researchers have argued that consumers' awareness regarding green products has not reached the level where those green products are viewed as alternatives to the traditional products (Abdul Wahid \& Rahbar, 2011).

Researchers found that green awareness affects green purchase behavior directly (Mei et al., 2012). Kauffman et al. (2012) found that governments have a significant role in creating customers' environmental awareness through educating and cultivating environmental concern among the public. Additionally, media is directly affecting the environmental awareness by presenting the effects of the environmental problems on mankind (Kim \& Chung, 2011). Today, firms are putting major efforts to promote green products through building a positive image in order to affect the consumers' purchase decision.

\subsection{Green Trust}

Trust is defined as confidence that the other party will act according to one's expectations (Alsaad et al., 2014). Also, from another perspective trust can be seen as the intention to accept vulnerability based on positive expectations of the integrity and capability of another one ( $\operatorname{Lin} \& \mathrm{Lu}, 2010)$.

Chen (2010) used the factor "green trust" in his study and referred to it as the consumers' incentive to have confidence in the product upon its' eco- friendly claims. One of the factors that has a major influence on the customer's behavior is customer trust. Previous literature indicated that customer's trust would increase the commitment to buying the product ( $\mathrm{Li}$ et al., 2011). The definition of the environmental product basically relies on confidence as consumers cannot definitely judge if the product is certainly ecological even after their consumption (Thompson et al., 2010).

A study was conducted in 2011 regarding the customers' trust in green labeling and green branding revealed a positive influence on their purchase behavior (Rahbar \& Nabsiah, 2011). The study highlighted that businesses should try to increase the consumer's green trust by using credible messages in order to enthuse green purchase behavior.

\subsection{Demographic Profile of the Green Consumer}

Substantive studies have been conducted on the characteristics of the green consumer, yet no agreement has been reached regarding the exact demographics.

Many studies have concentrated on demographics since they were found to have an impact on the consumer's actions and attitudes and hence will affect their environmental buying behavior.

Sidique et al. (2010) tried to explain the effect of the differences in consumer's demography on the consumer's attitude towards buying eco-friendly products, the variables that had an effect on purchase behavior were gender, age, ethnic group, education level, marital status and number of children.

In Spain, some researchers indicated that buyers who regularly purchase green and organic products are mainly young people who are highly educated (Zamora et al., 2013). In Germany, it was found that those consumers earn higher income and have higher education (Franzen \& Meyer, 2010). In Greece, a study was conducted on green purchase and found that age has no effect on buying green products (Tilikidou \& Delistavrou, 2012.). Additionally, a survey was conducted in Greece on 420 households to study the pro-environmental purchase behavior and the study concluded that citizens who adopt pro-environmental behaviors more frequently are highly educated people with higher income (Arslan et al., 2012).

According to Boztepe (2012), a study was conducted in Britain on the demographic variables to determine the profile of the green consumer; this study found a negative correlation between age and pro-environment behavior and a positive correlation between education in relation to intention and behavior.

\subsubsection{Age}

Many researchers have tried to study the effect of Age on green behavior but there has been a strong debate in literature. Some researchers discussed the significant effect of age over environmental buying behavior while others found that there is no relationship between age and environmental behavior (Arttachariya, 2012). A study conducted in 2011 presented the evolving awareness of old consumers about the green products which was reflected in their purchase behavior (Singh, 2011).

Whereas Akehurst et al. (2012) conducted a study on green behavior and found out that younger people are more sensitive to sustainability issues. A similar study highlighted that the consumers who are most likely to purchase environmental products are younger in age (Tung et al., 2012). The emphasis on young consumers is logical since they represent a new market segment with a major impact on the environment. 


\subsubsection{Education Level}

Researchers have argued that the level of consumers' education is directly related to purchasing behaviors (Kaufmann et al., 2012). The major reason was because the educated consumers are more alert to the environmental consequences. Moreover, Sidique et al. (2010) found a positive relation between education and environmental behavior.

\subsubsection{Income Level}

Individuals with high income show more environmental concerns and buy more green products (Junaedi, 2012). In general, the income level will have an influence on green purchase since the consumers with higher level of income will be the ones able to afford the premium price of green products. Additionally, a recent study conducted by Boztepe (2012) revealed that consumers from middle income group show green purchase intention since they are becoming more aware of the environmental problems and their effect on sustainability.

\subsection{Environmental Buying Behavior}

Nowadays consumers have become more alarmed with their daily purchasing habits and their impact on the environment and accordingly became more convinced in buying green products (Kalantari \& Asadi, 2010). As environmental awareness was on the rise, it had major consequences on consumer green behavior.

Zhuang et al. (2010) stated that both ecological awareness and knowledge are the utmost important factors in affecting the environmental buying behavior. Whereas other researchers indicated that businesses should elevate the level of green trust in order to prompt green purchase behavior (Thompson et al., 2010).

\subsection{Jordanian Market Characteristics}

Jordan is an upper middle-income country with a population of 6 million of which 80 percent is considered urban, moreover Jordan is considered one of the youngest among upper-middle income countries, the country has limited natural resources, limited agricultural land, and water is especially scarce (World Bank Report, 2012).

Jordan is facing major restrictions caused by high population growth rate, pollution and lack of water resources (Jordan national strategy). All of these limitations force the public to consider their responsibilities towards the environment in order to sustain a better future for the generations to come. Jordan should focus on increasing the environmental awareness among its population at the level of the individuals and decision-makers alike. The First law to protect the environment was stated in 1995 by the Jordanian government, and it entailed resource conserving, environmentally-friendly strategies and legislations in all the stages and began to force firms to alter their operations and to implement green strategies (Ministry of environment, 2014).

Jordanian consumers are just at the phase of green initiation. There are few researches available in Jordan regarding environmental responsibility or green marketing (Abu-Elsamen \& Al-Dmour, 2011), and the green market is considered a niche market in Jordan, and even though green products are present in some locations in Jordan and specifically in Amman, the trend of green is still new to the Jordanians. Jordanian consumers can be categorized as environmentally aware, yet this awareness is not translated into real buying behavior (Alsmadi \& Alnawas, 2012). At first, foreign firms began to promote environmental products in Jordan. In addition, The World Bank (2012) has funded a number of environmental projects in some areas across Jordan. But today some stores, restaurants, hotels, and even schools have adopted green strategies in order to promote themselves as environmentally-friendly companies (Jordan Environmental Information System, 2013). Major stores are offering recycling locations in their sites (Cozmo, 2014). Some banks have provided green loans for both households and firms for the purpose of sustainable development and energy saving (Al Ahli Bank, 2014). In addition, many environmental awareness campaigns have been conducted by ministries and nongovernmental organizations in order to encourage green behaviors. Also according to the National Agenda, there is an effort to include environmental education and awareness at all levels of the education system.

\section{Conceptual Framework}

Different prior studies concluded that green awareness has a direct impact on green purchase behavior (Zhuang et al., 2010; Kalantari \& Asadi, 2010). In addition, green trust was found to have a direct relationship with the green behavior (Rahbar \& Nabsiah, 2011; Thompson et al., 2010). Demographic variables were also found to have a significant impact on the consumers' pro-environmental buying behavior ( $\mathrm{Lu}$ et al., 2010) and several researchers have tried to measure the effect of demographic variables on green buying behavior (Boztepe, 2012). For the present study the following demographic variables were taken into the analysis: age, income and education level. 
Age was investigated by many authors and some of them argued that there is no correlation between age and environmental behavior (Arttachariya, 2012), while others argue that young people are likely to be more sensitive to green marketing issues (Akehurst et al., 2012).

Income has been always perceived to have a positive impact on environmental consumer behavior due to the general assumption that most green products have higher prices than conventional ones. Many authors took this variable into their analyses and found out that consumers with high income showed more tendency to buy eco-friendly products (Junaedi, 2012).

The vast majority of studies that included education level have found a positive relationship with environmental consumer behavior (Sidique et al., 2010).

\subsection{Theoretical Framework}

\section{Independent Variables}

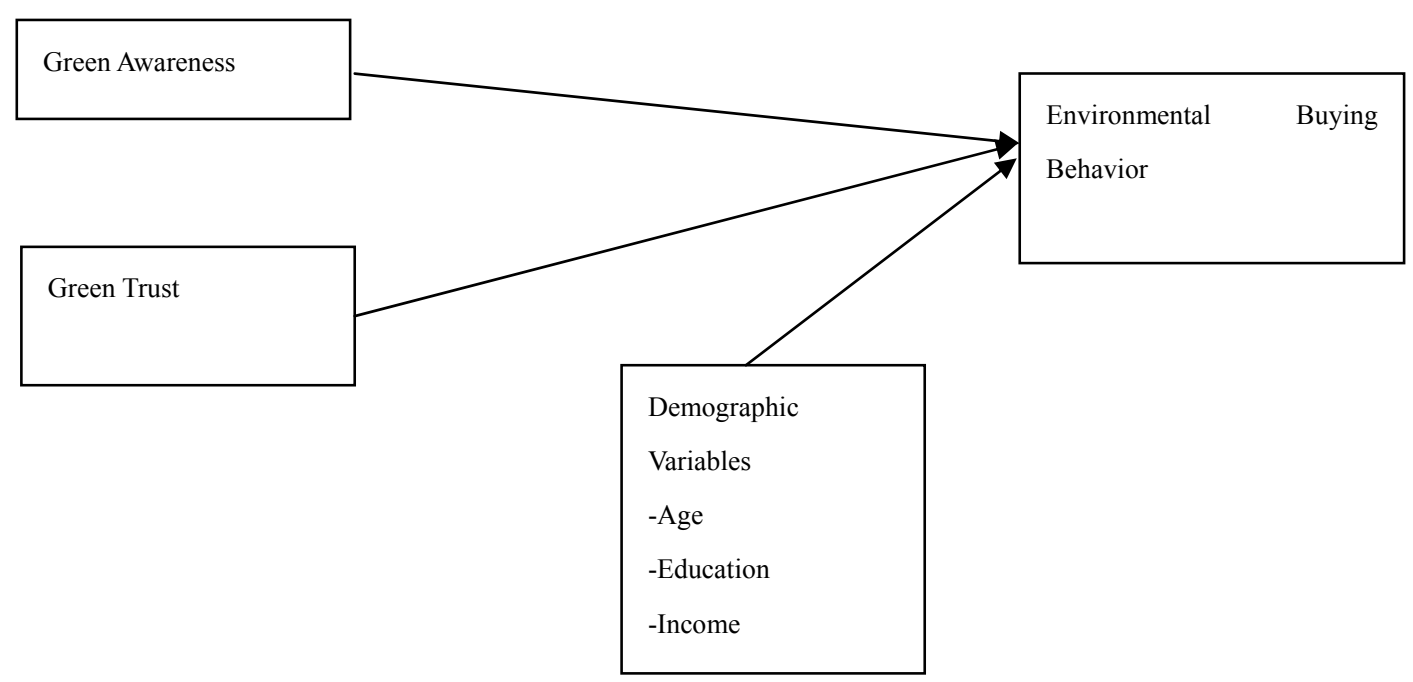

Figure 1. Research theoretical framework

\subsection{Hypotheses Development}

The research aimed to test the following three hypotheses:

H1: There is no significant relationship between the consumer's green awareness and the environmental buying behavior.

H2: There is no significant relationship between the consumer's green trust and the environmental buying behavior.

H3: There is no difference between "the household's characteristics such as: "age, educational level and income level" and the environmental buying behavior taken separately.

\subsection{Research Population and Sample Size}

The study population was identified as the consumers who regularly buy green products in Amman area and the questionnaire method was used. The questionnaires were distributed manually in locations selling green products. Green marketing phenomena is still in its infancy stage in the Jordanian Market. However, nowadays it is promoted by some environmental consciousness of consumers (Alsmadi \& Alnawas, 2012). Basing on similar studies, the sample size for this study was determined to be 400 consumers. The non-probabilistic technique used was the convenience sampling. The subject of the sample was the consumers who play roles in the buying behavior for household products and shop from locations selling green products in addition to people who have previous experience with green products.

A total of 342 questionnaires were returned. The response rate of the survey was $85 \%$, which is close to the range of the response rate of similar studies (Aman et al., 2012; Gam et al., 2010). 


\subsection{Findings of the Hypotheses}

The sample characteristics according to the different demographic variables starting with the age, most of the sample respondents' age was between 35-44 years as its percent was 30.1 percent followed by 27.2 percent to the group age between 18-24 then by 17.5 percent to 25-34 years. According to the educational level, the sample revealed that the majority are holding a bachelor degree with 48.2 percent and 20.5 percent are holding a post graduate degree. The university students were 16.4. And the ones holding diplomas and high school degrees were 13.7 and .6 percent respectively. Additionally, the distribution of the results according to the monthly income level for the respondents indicated that the highest group were people who earn 1000-1499 JD with 39.2 percent followed by consumers earning 1500-1999 JD with a percentage of 36 .

To test the hypothesis, Multiple Regression and One Way Analysis of Variance and Tukey's post hock tests were conducted and the results are showed as following.

Table 1. Coefficients

\begin{tabular}{llllll}
\hline & \multicolumn{3}{c}{ Unstandardized Coefficients Standardized Coefficients } & \multicolumn{2}{c}{ Results } \\
\cline { 2 - 4 } Model & $\mathrm{B}$ & Std. Error & Beta & $\mathrm{T}$ & Sig. \\
\hline (Constant) & -.088 & .139 & & -.620 .532 \\
Green Awareness & .228 & .065 & .243 & 3.655 .000 Reject the null hypothesis \\
Green Trust & .165 & .069 & .163 & 2.543 .011 Reject the null hypothesis \\
\hline
\end{tabular}

\subsubsection{First Hypothesis}

There is no significant relationship between the consumer's green awareness and the environmental buying behavior.

The multiple regression was used to test the first hypothesis. Table 1 showed the estimation of beta for green awareness which is equal to .228. Table 1 also illustrated the analysis of coefficients and presented the value of significance for green awareness which was equal to .000 . The value is below .05. Consequently, the researchers rejected the null hypothesis and accepted the alternative hypothesis which means that a significant relationship exists between the consumer's green awareness and the environmental buying behavior.

\subsubsection{Second Hypothesis}

There is no significant relationship between the consumer's green trust and the environmental buying behavior.

The multiple regression was also used to test the second hypothesis. Table 1 showed the estimation of beta for green trust which is equal to .165 . Table 1 also illustrated the analysis of coefficients and presented the value of significance for green awareness which was equal to .011. The value is below .05. Consequently, the researchers rejected the null hypothesis and accepted the alternative hypothesis which means that a significant relationship exists between the consumer's green trust and the environmental buying behavior.

\subsubsection{Third Hypothesis}

There is no difference between "the household's characteristics such as: "age, educational level and income level" and the Environmental Buying Behavior taken separately.

1). Age

Table 2 presented the means and standard deviation of the environmental buying behavior according to the different age categories. The different groups showed a high tendency to buy green products as all the means were somehow high. Table 3 demonstrated if the difference in age affected the environmental buying behavior; the values were higher than 0.05 which means that there is no statistical difference between the different age groups. 
Table 2. Means and standard deviation of environmental buying behavior according to age

\begin{tabular}{|c|c|c|c|c|c|}
\hline \multirow[t]{2}{*}{ Environmental Buying Behavior } & & \multirow[t]{2}{*}{ Mean } & \multirow[t]{2}{*}{ Standard Deviation } & \multicolumn{2}{|c|}{$95 \%$ Confidence interval for Mean } \\
\hline & & & & Lower Bound & Upper Bound \\
\hline & $18-24$ & 3.97 & 0.44 & 3.89 & 4.05 \\
\hline & $25-34$ & 3.96 & 0.50 & 3.79 & 4.13 \\
\hline & $35-44$ & 3.73 & 0.72 & 3.57 & 3.90 \\
\hline & $45-54$ & 3.86 & 0.41 & 3.67 & 4.05 \\
\hline & 55 and above & 3.84 & 0.75 & 3.68 & 4.00 \\
\hline
\end{tabular}

Table 3. One way analysis of variance for the differences in environmental buying behavior according to age

\begin{tabular}{lllllll}
\hline & & Sum of Squares & Df & Mean Square & F & Sig. \\
\hline Environmental Buying Behavior & Between Groups & 2.947 & 4 & 0.737 & 2.002 & 0.094 \\
& Within Groups & 124.021 & 337 & & & \\
& Total & 126.968 & 341 & & & \\
\hline
\end{tabular}

\section{2). Education}

The researchers investigated the differences caused in the environmental buying behavior due to the educational levels. Table 4 and 5 showed that statistically there is difference in green purchase behavior according to educational levels.

Table 4 presented the means and it revealed that all categories had a high tendency to buy green products. Particularly, University students, holders of bachelors and post graduate degrees have a higher mean than diploma degrees.

Results in table 5 demonstrated that values were significant because it was below 0.05 which means that there is a statistical difference in environmental buying behavior according to educational level.

Table 6 showed that the source of variation in the environmental behavior is between the high school and diploma degree holders in one side and the university students and bachelor and post graduate degree holders on the other side.

Table 4. Means and standard deviation of environmental buying behavior according to educational level

\begin{tabular}{|c|c|c|c|c|c|}
\hline \multirow{3}{*}{$\begin{array}{l}\text { Environmental } \\
\text { Buying Behavior }\end{array}$} & & \multirow[t]{3}{*}{ Mean } & \multirow{3}{*}{$\begin{array}{l}\text { Standard } \\
\text { Deviation }\end{array}$} & \multicolumn{2}{|c|}{$95 \%$ Confidence interval for Mean } \\
\hline & & & & Lower & Upper \\
\hline & & & & Bound & Bound \\
\hline & Diploma & 3.24 & 1.16 & 2.91 & 3.58 \\
\hline & University students & 4.00 & .37 & 3.92 & 4.03 \\
\hline & Bachelor & 3.97 & .47 & 3.87 & 4.12 \\
\hline & Post Graduate & 3.97 & .28 & 3.90 & 4.03 \\
\hline
\end{tabular}

Table 5. One way analysis of variance for the differences in environmental buying behavior according to educational level

\begin{tabular}{lllllll}
\hline & & Sum of Squares & Df & Mean Square & F & Sig. \\
\hline Environmental Buying Behavior & Between Groups & 22.777 & 4 & 5.694 & 18.418 & .000 \\
& Within Groups & 104.191 & 337 & .309 & & \\
& Total & 126.968 & 341 & & \\
& & &
\end{tabular}


Table 6. Tukey's post hock comparisons in the environmental buying behavior according to educational level

\begin{tabular}{llllll}
\hline & & & $\begin{array}{l}\text { University } \\
\text { Students }\end{array}$ & $\begin{array}{l}\text { Bachelor } \\
\text { Degree }\end{array}$ & $\begin{array}{l}\text { Post } \\
\text { graduate }\end{array}$ \\
\hline Environmental Buying Behavior & High School & -0.08 & $-.23^{*}$ & $-.19^{*}$ &.$- .21^{*}$ \\
& Diploma & & -0.15 & -0.11 & -0.13 \\
& University Students & & & 0.03 & 0.02 \\
& Bachelor Degree & & & & -0.02 \\
\hline
\end{tabular}

3). Income

The researchers examined the differences caused in the environmental buying behavior due to the income levels. Table 7 showed that all categories' means are higher than 3.5 which indicates that all have high level of environmental buying behavior, the uppermost was found among the income level of 2000JD and above with a mean of 4.13. Table 8 demonstrated that there is statistically difference in environmental buying behavior according to income level, as all the values are significant below 0.05 .

According to Table 9 the source of difference in the environmental buying behavior was between the consumers earning lower level of income in one side and with the consumers earning more than 1000 JDS on the other sides.

Table 7. Means and standard deviation of environmental buying behavior according to income level

\begin{tabular}{|c|c|c|c|c|c|}
\hline \multirow[t]{3}{*}{ Environmental Buying Behavior } & & \multirow[t]{3}{*}{ Mean } & \multirow[t]{3}{*}{ Standard Deviation } & \multicolumn{2}{|c|}{$95 \%$ Confidence interval for Mean } \\
\hline & & & & Lower & Upper \\
\hline & & & & Bound & Bound \\
\hline & Less than $500 \mathrm{JD}$ & 4.11 & 0.36 & 3.90 & 4.33 \\
\hline & 500- 999 JD & 3.74 & 0.86 & 3.59 & 3.90 \\
\hline & 1000-1499 JD & 3.97 & 0.39 & 3.90 & 4.03 \\
\hline & 1500-1999 JD & 3.79 & 0.41 & 3.68 & 3.90 \\
\hline & $2000 \mathrm{JD}$ and above & 4.13 & 0.19 & 4.04 & 4.22 \\
\hline
\end{tabular}

Table 8. One way analysis of variance for the differences in environmental buying behavior according to income level

\begin{tabular}{lllllll}
\hline & & Sum of Squares & Df & Mean Square & F & Sig. \\
\hline Environmental Buying Behavior & Between Groups & 5.639 & 4 & 1.410 & 3.915 & .004 \\
& Within Groups & 121.329 & 337.360 & & \\
& Total & 126.968 & 341 & & & \\
\hline
\end{tabular}

Table 9. Tukey's post hock comparisons in the environmental buying behavior according to income level

\begin{tabular}{|c|c|c|c|c|c|c|}
\hline & & & 500- 999 JD & $1000-1499$ JD & $\begin{array}{l}1500-1999 \\
\text { JD }\end{array}$ & $\begin{array}{l}2000 \mathrm{JD} \text { and } \\
\text { above }\end{array}$ \\
\hline Environmental & Buying & Less than $500 \mathrm{JD}$ & -0.13 & $-.42 *$ & $-.26^{*}$ & -0.17 \\
\hline \multirow[t]{3}{*}{ Behavior } & & 500- 999 JD & & -0.31 & -0.18 & -0.05 \\
\hline & & 1000-1499 JD & & & 0.16 & 0.26 \\
\hline & & 1500-1999 JD & & & & 0.11 \\
\hline
\end{tabular}

\section{Conclusion, Recommendations, and Future Research Suggestions}

The study tries to highlight the effect of green awareness, green trust and demographic characteristics of the Jordanian consumers who purchase green products, in order to develop more effective marketing campaigns by the marketers.

The results present a clearer perspective to marketers in order to classify the consumer environmental buying behavior for improved segmentation, targeting and positioning of market. This study provides a number of 
practical implications for marketers in enhancing consumers' green behavior.

The results highlight the relationship between green awareness and green buying behavior. Analysis of the green terminology can be valuable to inducing demand for these products and in developing communication strategies in emerging markets. Marketers need to emphasize the environmental awareness and knowledge in their actions in order to change the consumer purchasing behavior.

As for green trust, the results of the study offer several managerial implications. First, marketers should reinforce the role trust plays in encouraging green behavior. Companies should also focus on offering trustworthy information that assists in building trust and enhances the environmental purchase behavior.

As by knowing the demographics of the market segment, this will create a successful campaign that will have a positive impact on the environmental buying behavior. The results there is a statistical difference in environmental buying behavior according to educational level; as people get higher educational certificates, they tend to buy more green products, and this can be explained that those consumers are more aware of the benefits of those products whether their effect to the environment or themselves directly. Moreover, consumers with higher income were found to have more tendency to buy green products and this is due to the fact that they can afford to spend more in order to buy green products, thus marketers should develop strategies targeting consumers obtaining middle to higher levels of income, and marketers should also know where this segment exists so they can direct their campaign towards them.

Some suggestions for future researchers, the model of the study implies the future space for adding new demographic variables as occupation, marital status and number of family members to examine their impact on the environmental buying behavior, as this will also add a good contribution and will help the managers in developing the marketing activities to be more precise in targeting this niche market. Additionally, since the Jordanian market behaved differently, a comparative study can be conducted with other markets, while trying to understand the differences relying on cultural attitudes. Moreover, this research is based on cross-sectional data meaning that it is only able to analyze the purchase behavior pattern of the Jordanian consumer at one point of time. For future researches a longitudinal study should be conducted in order to analyze the sequential change in the factors affecting environmental buying behavior in the Jordanian market.

\section{References}

Abdul, W. N., \& Rahbar, E. (2011). Investigation of green marketing tools 'effect on consumer' purchase behaviour. Business Strategy Series, 12(2), 73-83. http://dx.doi.org/ 10.1108/17515631111114877

Abu, E. A., \& Al, D. H. (2011). An empirical examination of inter- organizational factors influence on green marketing adoption in Jordanian industrial sector. Studies in Business and Economic, 16(1), 5-18.

Akehurst, G., Afonso, C., \& Gonçalves, H. (2012). Re-examining green purchase behavior and the green consumer profile: New evidences. Management Decision, 50(5), 972-988. http://dx.doi.org/10.1108/00251741211227726

Akter, J. (2012). Consumer Attitude towards Green Marketing in Bangladesh. ASA University Review, 6(1).

Alahli Bank. (2014). Go Green Loan. Retrieved from http://www.ahli.com/go_green_loan.shtm

Alsaad, A., Rosli, M., \& Ismail, N. (2014). The Moderating Role of Power Exercise in B2B E-commerce Adoption Decision. Social and Behavioral Sciences, 130(15), 515-523. http://dx.doi.org/10.1016/j.sbspro.2014.04.060

Alsmadi, S., \& Alnawas, I. (2012). Consumer Rights Today: Are They in Business or Out of Business? Journal of Promotion Management, 4(1), 159-167. http://dx.doi.org/10.5539/ijms.v4n1p159

Aman, L., Harun, A., \& Hussein, Z. (2012). The Influence of Environmental Knowledge and Concern on Green Purchase Intention. British Journal of Arts and Social Sciences, 7(2), 145-163.

Arslan T., Yilmaz, V., \& Aksoy, H. (2012). Structural Equation Model for Environmentally Conscious Purchasing Behavior. International Journal of Environmental Research, 6(1), 323-334

Arttachariya, P. (2012). Environmentalism and Green Purchasing Behavior: A Study on Graduate Students in Bangkok, Thailand. Assumption University.

Axsen, J., TyreeHageman, J., \& Lentz, A. (2012). Lifestyle practices and pro environmental technology. Ecological Economics, 82, 64-74. http://dx.doi.org/10.1016/j.ecolecon.2012.07.013

Boztepe, A. (2012). Green marketing and its impact on consumer buying behavior. European Journal of Economic and Political Studies, 5(1), 5-21. 
Carrete, L., Castano, R., Felix, R., Centeno, R., \& Gonzales, E. (2012). Green consumer behavior in an emerging economy: Confusion, credibility, and compatibility. Journal of Consumer Marketing, 29(7), 470-480. http://dx.doi.org/10.1108/07363761211274983

Chen, Y. S. (2010). The drivers of green brand equity: Green brand image, green satisfaction, and green trust. Journal of Business Ethics, 93(2), 307-319. http://dx.doi.org/10.1007/s10551-009-0223-9

Cozmo Stores. (2014). Company social responsibility. Retrieved from http://www.cozmo.jo/corporate_responsibility.htm

Fanak Chronicle Saudi Arabia. (2015). Fanak Chronicle Saudi Arabia. Retrieved from https://chronicle.fanack.com/saudi-arabia/facts-and-figures/geography-and-climate/environmental-issues/

Franzen, A., \& Meyer, R. (2010). Environmental attitudes in cross-national perspective: A multilevel analysis. European Sociological Review, 26(2), 219-234. http://dx.doi.org/10.1093/esr/jcp018

Gam, H., Cao, H., Farrl, C., \& Kang, M. (2010). Quest for the eco-apparel market: A study of mothers' willingness to purchase organic cotton clothing for their children. International Journal of Consumer Studies, 34, 648-656. http://dx.doi.org/10.1111/j.1470-6431.2010.00898.x

Gul, M. (2013). Long-term Orientation, Perceived Consumer Effectiveness, and Purchase Intention for Green Products. International Journal of Marketing Studies, 6(5), 81-100.

Jordan Environmental Information System. (2013). National projects. Retrieved from http://www.jeis.gov.jo/En/Default.aspx

Junaedi, S. (2012). The Role of Income Level in Green Consumer Behavior: Multigroup Structural Equation Model Analysis. Paper presented at the 2012. International Conference on Business and Management, 6-7 September Phuket-Thailand.

Kadirov, D., \& Varey, R. (2010). The Companion Community: How Car Producers Promote Hybrid Car Consumption. Journal of Research for Consumers, 17, 2-17.

Kalantari, Kh., \& Asadi, A. (2010). Designing a structural model for explaining environmental attitude and behaviour of urban residents (Case of Tehran). International Journal of Environmental Research, 4(2), 309-320.

Kaufmann, R., Panni, M., \& Orphanidou, Y. (2012). Factors affecting consumers' green purchasing behavior: An integrated conceptual framework. Amfiteatru Economic, 15(31), 50-69.

Kim, Y., \& Chung, E. (2011). Consumer purchase intention for organic personal care products. Journal of Consumer Marketing, 28(1), 40-47. http://dx.doi.org/10.1108/07363761111101930

Kulshrestha, S. (2013). The Green Revolution In Marketing - Is It Worth? Indian Journal of Applied Research, $3(7), 431-433$.

Kumar, S. (2012). Green and conditional marketing: A reform of unethical values in pharmaceutical industry. International Journal of Engineering and Management Sciences, 3(1), 60-66.

Li, S., Huang, Y., \& Yang, M. (2011). How satisfaction modifies the strength of the influence of perceived service quality on behavioral intentions. Leadership in Health Services, 24(2), 91-105. http://dx.doi.org/10.1108/17511871111125675

Lin, L., \& Lu, C. (2010). The influence of corporate image, relationship marketing, and trust on purchase intention: The moderating effects of word of mouth. Tourism Review, 65(3), 16-34. http://dx.doi.org/10.1108/16605371011083503

Ling, C. Y. (2013). Consumers' purchase intention of green products: An investigation of the drivers and moderating variable. Marketing Management, 57, 503-509.

Lu, Y., Zhao, L., \& Wang, B. (2010). From virtual community members to C2C e- commerce buyers: Trust in virtual communities and its effect on consumers' purchase intention. Electronic Commerce Research and Applications, 9(4), 346-360. http://dx.doi.org/10.1016/j.elerap.2009.07.003

Mei, O. J., Ling, K. C., \& Piew, T. (2012). The Antecedents of Green Purchase Intention among Malaysian Consumers. Asian Social Science, 8(13), 248-263. http://dx.doi.org/10.5539/ass.v8n13p246

Ministry of Environment. (2014). Awareness campaigns. Retrieved from http://www.moenv.gov.jo/AR/Pages/Environmental-Awareness.aspx 
Mohajan, H. (2011). Green marketing is a sustainable marketing system in the twenty first century. International Journal of Management and Transformation, 6(2), 23-39.

Mondejar, J., Cordente, M., Meseguer, L., \& Gazquez, C. (2011). Environmental behavior and water saving in Spanish housing. International Journal of Environmental Research, 5(1), 1-10.

Rahbar, E., \& Nabsiah A. (2011). Investigation of green marketing tools' effect on consumers' purchase behavior. Business Strategy Series, 12(2), 73-83. http://dx.doi.org/10.1108/17515631111114877

Saleki, Z., Seyedsaleki, Z., \& Rahimi, M. (2012). Organic Food Purchasing Behavior in Iran. International Journal of Business and Social Science, 3(13), 278-285.

Sharma, Y. (2011). Changing consumer behavior with respect to green Marketing-A case study of consumer durables and retailing. International Journal of Multidisciplinary Research, 4(1), 152-162.

Sidique, F., Lupi, F., \& Joshi, S. (2010). The effects of behavior and attitudes on drop-off recycling activities. Resources, Conservation and Recycling, 54, 163-170. http://dx.doi.org/10.1016/j.resconrec.2009.07.012

Singh, S. (2011). A Study of Consumer Behavior of Elderly Consumers with Special Reference to Green Products. International Journal of Management and Information Systems, 15(4), 101-109.

Thompson, D., Anderson, R., Hansen, E., \& Kahle, L. (2010). Green segmentation and environmental certification: Insights from forest products. Business Strategy and the Environment, 19(5), 319-334. http://dx.doi.org/10.1002/bse.647

Tilikidou, I., \& Delistavrou, A. (2012). The Components of Pro-Environmental Purchasing Behavior. Proceedings of the International Conference on Contemporary Marketing Issues, 549-555. http://dx.doi.org/10.1108/MIP-10-2012-0103

Tung, J., Shih, C., Wei, S., \& Chen, H. (2012). Attitudinal inconsistency toward organic food in relation to purchase intention and behavior an illustration of Taiwan consumers. British Food Journal, 114(7), 997-1015. http://dx.doi.org/10.1108/00070701211241581

World Bank Projects. (2012). Retrieved from http://www.worldbank.org/en/country/jordan/projects

World Bank. (2012). Retrieved from http://www.worldbank.org/en/country/jordan/overview

World Health Organization. (2015). Retrieved from http://www.who.int/heli/risks/ehindevcoun/en/

World Wide Fund for Nature. (2015). Retrieved from http://wwf.panda.org/who_we_are/wwf_offices/south_africa/environmental_problems_in_south_africa/

Wu, S., \& Chen, Y. (2014). The Impact of Green Marketing and Perceived Innovation on Environmentally Conscious Consumer Behavior. International Journal of Marketing Studies, 5(5), 24-30. http://dx.doi.org/10.5539/ijms.v6n5p81

Zagata, L. (2012). Consumers' beliefs and behavioral intentions towards organic food. Evidence from the Czech Republic. Appetite, 59(1), 81-89. http://dx.doi.org/10.1016/j.appet.2012.03.023

Zamora, M., Rosab, M., Armenterosc, E., \& Ruiz, F. (2013). A Powerful Word: The Influence of the Term 'Organic' on Perceptions and Beliefs Concerning Food. International Food and Agribusiness Management Review, 16(4), 51-76.

Zhuang, W., Cumiskey, K. J., Xiao, Q., \& Alford, B. L. (2010). The impact of perceived value on behavior intention: An empirical study. Journal of Global Business Management, 6(2), 1-7.

\section{Copyrights}

Copyright for this article is retained by the author(s), with first publication rights granted to the journal.

This is an open-access article distributed under the terms and conditions of the Creative Commons Attribution license (http://creativecommons.org/licenses/by/3.0/). 